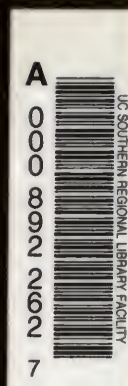

Dillingham

A Tribute to the Memory

Peter Coflinson

QK

31

C58 D5 




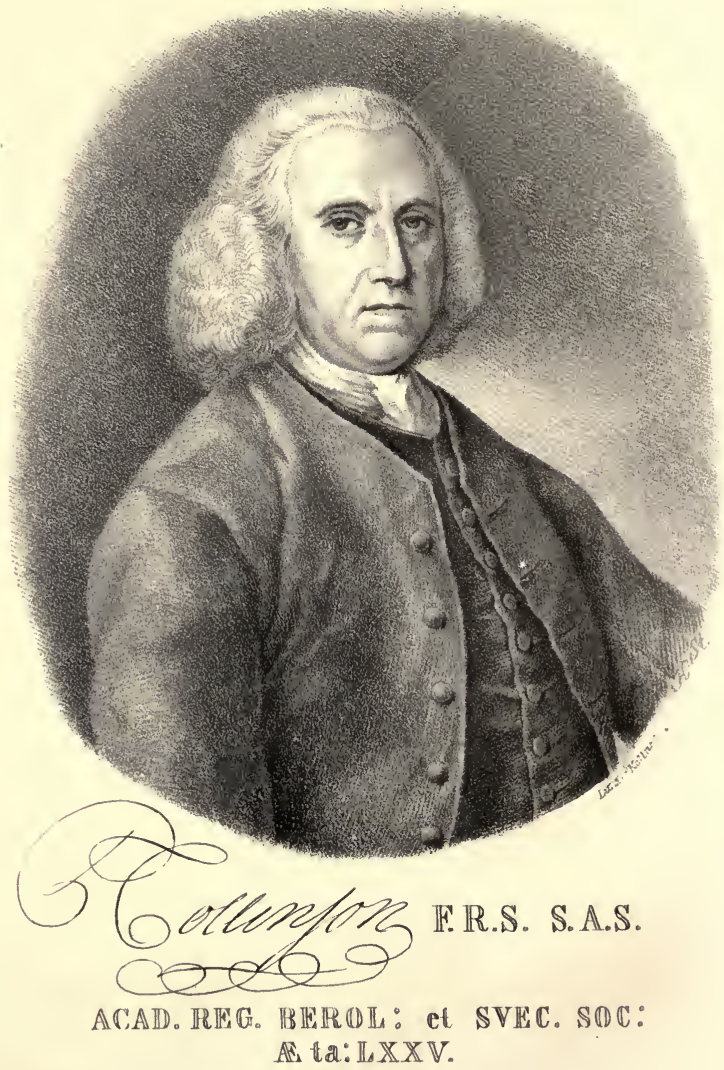




\section{TRIBUTE TO THE MEMORY}

OF

\section{PETER C OLLINSON.}

WITH SOME NOTICE OF

DR. DARLINGTON'S MEMORIALS

OF

JOHN BARTRAM AND HUMPHRY MARSHALL.

Second Edition,

WITH ADDITIONAL NOTES AXD AN APPENDIX.

B Y W M. H. DILLINGHAM.

PHILADELPHIA:

HENRY LONGSTRETH, 347 MARKET STREET, 1852 . 


\section{1 t}

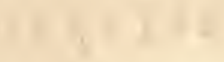

(1)

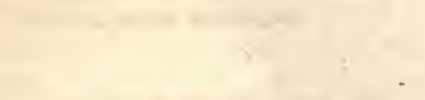

402040,4

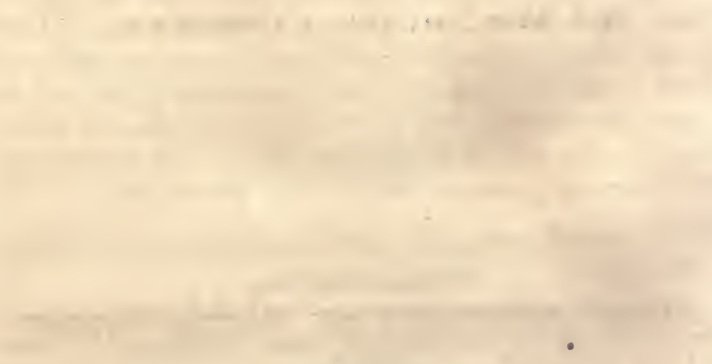




\section{PETER COLLINSON.}

THrs name indicates where those who would profit by the teachings of history may find a happy illustration of the many excellent traits of character which result from a life conformed to principles of Friends. The sect has been much criticised; the number of its adherents is limited in extent; we do not ourselves see things spiritual in the light they do, and we have heretofore expressed our dissent and given our reasons as occasion prompted.* But the truth of history must concede to them rare virtues, characterized as they are by self-denial, and eminent success in their efforts to relieve suffering humanity. Indeed they deny themselves the use of some agencies which most Christians think powerful and effectual as means of doing good. They have had the test of time; they have had their trials, neither few nor small; they have been sifted and scanned; and, while differing from almost all the rest of the world in some great leading rules of life and conduct, they have persevered and have been sustained: after the lapse of more than two centuries, the world sees a vast product of good to the whole human family from the labours of these few men. $\dagger$ Upon whom else in the wide world, since time began, has the sun of truth shone with a brighter light to carry him to the dark recesses and secret depths of sorrow, suffering, sin and shame, to relieve the miseries of a brother sinner, a fellow immortal? Wherever man presents himself, of whatever race or kind;

* This was the expression of the Princeton Review, where the original article appeared.

$\dagger$ They seek to personify the practical benevolence which their name indicates, in humble imitation of the example set them by the one great "Friend of Sinners." 
however wrecked in body, in mind, or in estate; however savage, barbarous, and idolatrous; however vicious and corrupt, the slave of his appetites and passions; nay, however sunk in the depths of infamy and crime, Friends regard him still as a fellow creature, to whom "our Father in heaven" has imparted an immortal soul, and who, while life lasts, should be treated and cared for as a fellow traveller to eternity.*

Their success in these efforts has certainly been pre-eminent. Witness their treatment of the criminal and of the insane. We cite this as one of the good traits for which Friends are distinguished, and it is one which has contributed to give character to the age. Who does not rejoice to live in an age when the insane are no longer treated with cruelty, and when the most wretched in crime may be taught that there is still, for them even, a God of infinite mercy? How do we look back with wonder upon the thousands of years the world had existed before it was discovered that a grand panacea for diseases of the mind was to be found in the law of love? And how does the world seem to have forgotten that one came down from heaven "and abode awhile in the flesh," to teach man how he should treat his brother sinner, and to point the dying malefactor to the gate of heaven? For the general prevalence, blessed influence, and practical application of these truths, we are greatly indebted to Friends.

Their quiet virtues, happy amenities, and silent worth, do not attract the gaze of the world; but they will repay us for seeking out and looking into them. Their simple habits; their industry, integrity, and thrift; their pleasure in doing good; their intense interest in nature's varied handiwork; their estimate of things conducive to comfort, peace, and happiness, over things luxurious and things ostentatious; their abhorrence of war ; their active sympathy with all in distress, and their preference of the "good name which is better than precious oint-

* Many believe that there is a light in the breast of every human being which should enable him to discriminate between good and evil, and which, however it may become clouded and darkened, is never wholly extinguished while life lasts. To this spark of reason and conscience they address themselves with the law of brotherly kindness, and seek to kindle the light within. 
ment" over worldly glory, had all a faithful representative in Peter Collinson.* In their full representation we do not think the Society has produced his superior. We do not say that he was a better man than George Fox or William Penn; that he was so deep a thinker as Dr. Fothergill; that he did more to leave a name behind him than James Logan; that he was so great a naturalist as John Bartram; or that he relieved as much distress as Elizabeth Fry. But, studying his character as it has been recently developed, it does appear to us that he combined more of all these respective qualities than either of the individuals named. One who has done more than any other towards this development, and who understands the whole subject as well as any man living, says of him, in a manuscript now under our eye- "he was one of the earliest and most distinguished cultivators, and most distinguished patrons, of the Natural Sciences in the Society of Friends; and, at the same time, an honour and an ornament to the sect." It must be acknowledged that the same authority says of Dr. Fothergill, the intimate friend of Peter Collinson, that he "regards him as the most accomplished Quaker that ever lived, whether considered as a man of science, or as a philanthropist"-adding, "while the Society of Friends may ever be proud of their great lawgiver, Penn, the lovers of nature among them may boast of a Logan, a Collinson, a Fothergill, and a Marshall; to each of whom a genus has been dedicated, that will preserve the memory of their worth and services as long as the plants which bear their names shall continue to grow." But the preeminence in accomplishments among Friends, which our correspondent assigns to Dr. Fothergill, relates particularly to science and philanthropy. As a practical utilitarian, a helper of others to do good to their fellow-men, and to attain the heights and depths of scientific discovery; to push their researches through difficulties and dangers to earth's remotest bounds, and perhaps in some other characteristic excellencies, Peter Collinson surpassed him; although it must at the same time be confessed

* Enclosed in Peter Collinson's Will was found a paper importing, " that he hoped he should leave behind him a good name which he valued more than riches; that he had endeavoured not to live uselessly; and that all his days he constantly aimed to be a friend of mankind." 
also, he was not so good a Whig, nor so great a friend to our revolutionary movement.

Could we ask Dr. Franklin-" who, of all men, best deserved a statue, in commemoration of active, disinterested, and valuable services in building up the Philadelphia Library ?" he would say, "Peter Collinson." Those most knowing in the early history of this institution now say, that the marble which occupies a niche in its front, would have found a more fitting place in front of the Philosophical Hall opposite. Ask Franklin again, "from whom he derived the information, and who furnished him with the hints, and put, into his hands the actual means, whereby he made his splendid discovery of the identity of lightning and electricity," and he will tell you, "Peter Collinson."* It is melancholy to think that his thirty years gratuitous and invaluable services for the Library should have been terminated by this excellent man, as we have good authority to believe, under a sense that they had not been duly estimated by those having it in charge.

He was the only man in the Royal Society at London who appreciated Franklin's letters announcing his discovery; which, when first communicated there, were frowned down, sneered at, and refused a place in their published transactions. Peter Collinson had them published, drew the attention of knowing

* In Dr. Lettsom's edition of Dr. Fothergill's works we find a letter from Dr. Franklin to Michael Collinson, Esq., on the occasion of his father's death, dated "Craven Street, Feb. 8, 1770," from which we give an extract. After referring to and describing the valuable services rendered to the Philadelphia Library, by Peter Collinson, he goes on to say :

"During the same time he transmitted to the Directors of the Library the earliest accounts of every new European improvement in agriculture and the arts, and every philosophical discovery; among which, in 1745, he sent over an account of the new German experiments in electricity, together with a glass tube, and some directions for using it, so as to repeat these experiments. This was the first notice I had of that curious subject, which I afterwards prosecuted with some diligence, being encouraged by the friendly reception he gave to the letters I wrote to him upon it. Please to accept this small testimony of mine to his memory, for which I shall ever have the utmost respect; and believe me, with sincere esteem,

Dear Sir, your most obedient, humble servant,

B. FrankLin." 
men to them, excited admiration of the wonderful secret disclosed, and was among the very first to foresee and proclaim Franklin's undying renown.

He did more than any man living to help to make John Bartram what he became, and without his aid Bartram could never have accomplished one half his wonderful achievements. Dr. Fothergill goes so far as to say, "That eminent naturalist, John Bartram, may almost be said to have been created such by my friend's assistance,"-." constantly exciting him to persevere in investigating the plants of America, which he has executed with indefatigable labour through a long course of years, and with amazing success."

It is an interesting fact, that it should have been reserved for our own time and for our own country, to bring to light far more than was before known of the life, history, and scientific habits and correspondence of that eminent and excellent man, who was a London merchant, and who died about the middle of the last century. True, the English themselves acknowledge, that it was an American who first told them what they wanted to know about Sebastian Cabot. The Edinburg Reviewers, even before that, had found out that "they should soon learn to love the Americans if they sent them many more such books," as one which Robert Walsh had written about France.

The recent work by Dr. Darlington, a Pennsylvanian, has awakened deep interest in England, with regard to one of their own sons collaterally introduced, and is equally well spoken of on both sides of the water. It is entitled, "Memorials of John Bartram and Humphry Marshall;" but nearly one half of its five hundred and ninety-five pages of fair, large, open type, is occupied with the letters of Peter Collinson. No Philadelphian can read it without feeling that the next statue erected in the city of brotherly love after those of Penn and Franklin, and that contemplated in honour of Washington, should be one to perpetuate the memory of what she owes to Peter Collinson. Whoever reads it will find interesting matters of colonial history; minute particulars illustrating the character of the intercourse between this country and the old for fifty years before the Revolution, which he sees nowhere else.

But to return to Peter Collinson-since sounding his praises 
so loud, we must be permitted to call up Southey to our support. He thus sums up in few words, what was known and thought of this London friend of our own Logan, Franklin and Bartram, in his time:

"Peter Collinson, whose pious memory ought to be a standing toast at the meetings of the Horticultural Society, used to say that he never knew an instance in which the pursuit of such pleasure as the culture of a garden affords, did not find men temperate and virtuous, or make them so. And this may be affirmed as an undeniable and not unimportant fact relating to the lower classes of society, that whenever the garden of a cottage or other humble dwelling is carefully and neatly kept, neatness, and thrift, and domestic comfort will be found within doors.

"When Mr. Allison settled at Thaxed-Grange, English gardens were beginning generally to profit by the benevolent and happy endeavours of Peter Collinson to improve them. That singularly good man availed himself of his mercantile connection, and of the opportunities afforded him by the Royal Society, of which he was one of the most diligent and useful members, to procure seeds and plants from all parts of the werld, and these he liberally communicated to his friends. So they found their way first into the gardens of the curious, then of the rich, and lastly, when their beauty recommended them, spread themselves in those of ordinary persons. He divided his time between the counting-house in Grace-church street, and his country house and garden at Mill Hill near Hendon; it might have grieved him could he have foreseen that his grounds there would pass into the hands of a purchaser who in mere ignorance rooterl out the rarest plants, and cut down trees which were scarcely to be found in perfection anywhere else in the kingdom at that time.

"Mr. Collinson was a man of whom it was truly said that, not having any public station, he was the means of procuring national advantages for his country, and possessed an influence which wealth cannot purchase, and will be honoured when titles are forgotten. For thirty years he executed gratuitously the commissions of the Philadelphia Subscription Library, the first that was established in America; he assisted the directors 
in their choice of books, took the whole care of collecting and shipping them, and transmitted to the directors the earliest account of every improvement in agriculture and the arts, and of every philosophical discovery.

"Franklin, who was the founder of that library, made his first electrical experiments with an apparatus that had been sent to it as a present by Peter Collinson. He deemed it, therefore, a proper mark of acknowledgment to inform him of the success with which it had been used, and his first essays on electricity were originally communicated to this good man. They were read in the Royal Society, 'where they were not thought worth so much notice as to be printed in their transactions ;' and his paper in which the sameness of lightning with electricity was first asserted, was laughed at by the connoisseurs. Peter Collinson, however, gave the letters to Cave for the Gentleman's Magazine. Cave, forming a better judgment than the Royal Society had done, printed them separately in a pamphlet, for which Dr. Fothergill wrote a preface; the pamphlet by successive additions swelled to a volume in quarto, which went through five editions, and, as Franklin observes, 'cost Cave nothing for copy money.'

"What a contrast between this English Quaker and Monsieur La Cour at Leyden, who, having raised a double tuberose from the seed, and propagated it by the roots till he had as many as he could find room to plant, destroyed the rest as fast as they were produced, that he might boast of being the only person in Europe who possessed it."

We present this passage entire, from that curious book of miscellanies, "The Doctor," which having no index, and one part having no connection with another, except that each was written down by Southey, few know all the good things it contains. The author's allusion to Franklin and the conduct of the Royal Society, are in a spirit above the prejudices which sometimes influence the judgment of a poet-laureate, and there are some who will suspect that Southey was not aware of the high compliment he was bestowing upon this country in his praise of Peter Collinson; or, where it was that Peter found such extensive means of conferring good upon his fellow subjects of the kingdom of England. It has a marked emphasis 
as coming from a high churchman, in reference to a simple Quaker.

There is true magnanimity in the manner he speaks of, and leaves behind him an abiding testimonial to reprove, the Royal Society's treatment of Franklin's great discovery ; his political affinities, for the greater part of his life, were of the Wedderburne school, and those prejudices and partialities which influence most men, imparting a tinge to their feelings and clouding their judgments, were in sympathy with the king's attorneygeneral in his signally notorious arraignment of Franklin before the British nation.* Whoever looks at his likeness in the life just published by his son, will see more of the expression of a lover of truth and nature, than of a servile hanger-on to monarchy and aristocracy. Its pages tell us also, that in his college days he planned, with Coleridge and others, a settlement in this Western world, as Hampden and Cromwell had once done. He was, perhaps, the best informed man upon the greatest variety of subjects of his day; and, if we mistake not, will in time be judged more charitably by our countrymen.

But what about this book which tells us so much that we did not know before of Peter Collinson, without any reference to him in the title-page?

Its first few pages are devoted to a brief sketch of the progress of botany in North America-comprehensive and condensed-beginning with the work of Jac. Cornutus on the plants of Canada, published in 1635, and John Josselyn's New England rarities of 1672 , and coming down to the doings of the "accomplished and indefatigable" Asa Gray now in medias res. In looking over this sketch it is interesting to see such names as those of Logan, Clayton, Colden, Mitchell, and Muhlenberg, intimately connected with the history of natural science.

We next find a biographical sketch of John Bartram, principally taken from a work by his son; followed by a description of a visit to him at the age of seventy, purporting to be from

* Those who search out the secret springs of action which produce great events, may discover here what gave that intenseness to the animosity which prepared our countrymen for blood. 
the pen of a Russian gentleman, which is a perfect daguerreotype picture of him and his surroundings, giving us an equally life-like sketch of the inner as of the outer man.*

* As this paper is a literary curiosity, we copy a letter from "the honourable and venerable Samuel Breck, of Philadelphia," to be found in a note at page 44 of the memorials, which gives the following account of Hector Saint John de Creveceeur, who published letters as an American Farmer, and is now ascertained to have once appeared as Iwan Alexiowitz, the Russian gentleman referred to.

"In the year 1787 (says Mr. Breck) I arrived at Paris from the Royal and Military College of Soreze, in the then province of Languedoc, where I had spent more than four years. Thomas Jefferson, who was our plenipotentiary at the Court of Louis XVI., was travelling in Italy. A young Virginian, Mr. Short, received me in the minister's name, being his secretary, and made me acquainted with a very amiable Frenchman, who had resided in the United States, and written there a work, entitled, 'Letters from an American Farmer,' flattering and favourable to our country. This gentleman was Hector Saint John de Crevecœur. His work was exceedingly popular in France, and the fame acquired by it was a passport to the highest circles. The romantic descriptions in which he had indulged, in reference to the manners and primitive habits of our countrymen, made some of the great lords and ladies of Paris desirous to see a native American; among others a Polish princess took a fancy to see me, upon St. John's report to her of his acquaintance with me, and invited me to dine with her. I went there accompanied by Mons. Crevecour.

"That gentleman took me another day to dine with Mons. De Beaumenoir, at his apartments at the Hotel des Invalides, of which he was governor, and who had a daughter about to embark for New York, in the same packet that Mr. De Crevecour and I had both taken passage. She was coming out to America, under St. John's protection, to marry M. De La Forest, who was then French consul at New York, and afterwards became a man of some note, as a diplomatist under Napoleon, who raised him to the dignity of a baron of his empire. St. John himself had been made consul-general by King Louis.

"That kind friend took me, one morning, to visit Brissot De Warville, who served Philip d'Egalite (father of king Louis Phillippe) in some capacity, and had apartments at his residence, the Palais Royal. There we were received by Brissot. The Marquis de Valady, son-in-law of the Marquis de Vaudreuil, presented me with a copy of St. John's letters, which I still possess. St. John was by nature, by education, and by his writings, a philanthropist; a man of serene temper and pure benevolence; the milk of human kindness circulated in every vein; of manners unassuming, prompt to serve, slow to censure; intelligent, beloved, and highly 
The greater part of the volume is then taken up with the correspondence of John Bartram. The reminiscences of Humphry Marshall and his correspondence occupy comparatively few pages, but all instructive and interesting.

The letters of Peter Collinson spread over a period of thirtyfour years, and furnish a large portion of the materiel of which the work is composed. This materiel has been reclaimed from the dust, and mould, and lumber, of seventy years gone by, furbished up, arranged, and presented to us in an intelligible

worthy of the esteem and respect he everywhere received. His society on shipboard was a treasure.

" He had a daughter, whose early history was marked by passages sufficiently curious and eventful to make her the heroine of a novel. She married Mr. Otto, a French gentleman, who was an attaché, I think, to the Consular Office; and who rose under the revolutionary government of France to considerable diplomatic rank, even to the embassy to England for a short time."

The voyage above referred to is the same mentioned by Mr. Breck in his interesting letter recently published, wherein he describes New York as it appeared on his landing there, before we had a Constitution.

As it cost no little effort to trace the real authorship of the letter purporting to have been written by "a Russian gentleman," the result is here added; in a letter from the Editor of the "memorials."

\section{West Chester, April 17, 1851.}

Dear Sir: I think I mentioned to you, soon after the publication of the Memorials of Bartram and Marshall, that I had some doubts-even while compiling that work, whether the interesting account of a Visit to John Bartram, by "a Russian gentleman," named IWan Alexiowitz, was exastly what it purported to be. The fidelity of the sketch I could not doubt. But the failure of all my inquiries to learn any thing of such a visitor-together with the peculiarity of the name (which seems evidently coined for the wecasion,)-led me to suspect that the "Russian gentleman" was a fictitious character; and that Hестов ST. JоHN himself might have been the writer of the narrative. This suspicion. was greatly.strengthened by some contemporaneous criticisms of ST. JoHs's productions, which I afterwards saw in an old English catalogue of rare books, - wherein that gentleman was charged with the practice of writing under feigned names and characters: and I have recently come into possession of an autograph letter of Sт. JoHs, which entirely confirms me in the opinion, that the Visitor and Eulogist of "the celebrated Pennsylvania Botanist," was no other than the amiable and enthusiastic author of the Letters fiom an American Farmer.

The Autograph referred to, is a letter to the sons of JoIn BARTraM 
and attractive shape, without any apparent ambition on the part of the editor, but to do justice to his subject. His intense love of this is apparent from the care, and time, and labour bestowed upon it. That it was worth all it cost to bring these mouldering relics to light, every man of science, every man of sense, and every man of heart will say, who reads the book.

Some have thought it required sifting, and that there was some chaff which might be dispensed with in another edition. This may have been the general opinion on its first appearance; and we confess ourselves to have been of this mind until after perusing it carefully. But the oftener we read it, the more difficult do we find the task to point out anything that should be omitted-the more unwilling are we to part with a single page or an individual letter. It abounds in those blessed little a menities which go to make life happy and a book entertaining; intermixed with ten thousand minutiæ of the observations, studies and speculations of diligent inquirers into the secrets of Natural History, at the first dawn, as it were, of the sun of science. Its naiveté and simplicity, nay, its very imperfections even, add to its interest, after we become a little accustomed to them, inasmuch as they make it all a reality, taking us into the actual presence of those who lived a hundred years agone. The editor cannot fail to attract to himself some portion of

(viz. Willia and JoHs), and is chiefly filled with inquiries concerning plants and seeds; but commences as follows :-

"NeW YoRk, 26th December, 1783.

"Gentlemen : I have just received your kind letter; I am very happy to think you still remember the connection which once subsisted between your industrious parent and me. His industry, simplicity, and virtue, I have taken the liberty of recording in a book, called Letters from an American Farmer, published in London two years ago, the translation of which is now printing in Paris."

This extract seems, to me, to be conclusive of the question of the authorship of that graphic sketch of the Botanical Patriarch of our country, hitherto attributed to a Muscovite traveller.

Very Respectfully,

To Wr. H. Dillinghar, Philadelphia.

Wu. Darlington. 
the admiration he has awakened for those whose memory he embalms. The work is worthy of the expense, good taste, and artistic skill with which it has been presented to us by the publishers*, if it were only to illustrate the truth of what Linnæus said of Bartram, and what Fothergill said of Collinson's relations to him-" The greatest natural botanist in the world." This from one to whom botanists concede the title of "The immortal Swede," is, most truly-Laus, laudari a laudato virothe greatest natural botanist in the world, in the time of Linnæus, upon the authority of Linnæus! And Peter Collinson "may almost be said to have created him such !" The lovers of nature everywhere, to whom the London merchant pointed him out, regarded him with admiration; the savans of Europe anxiously sought his correspondence; nobles and princes patronized his labours, and learned societies conferred upon him the highest testimonials of esteem. He was not only a man of science, but a man of genius. He was also endowed with extraordinary capacities of body as well as mind, enabling him to endure fatigue, encounter danger, overcome difficulties, undergo privation, and persevere to the end, whatever great object he had in view. Like Newton, in simple facts he saw great principles, and traced them out with profound interest and untiring assiduity. Thus he became a man of great attainments. But he was not only a man of science, a man of genius, and a man of great capacities-he was a man of great virtues. His life is scarce more distinguished by his discoveries in the secrets of nature, than by his reverence for the great Author of those secrets, and love of his fellow creatures, for whose enjoyment in common with his own, they were in infinite wisdom contrived. His enthusiastic devotion to the study of nature's handiwork did not prevent his attention to the common business of life, the cultivation of his fields, provision for his family, building his house "with his own hands," "training up his children in the way in which they should go," and settling them in life. He was prudent, temperate, charitable, hospitable, maintaining a strict regard for the rights of others, and being scrupulously attentive to all the proprieties of life. It is among the most striking and interesting things to be remarked upon the long and cherished intimacy between him * Messrs. Lindsay \& Blakiston. 
and the excellent Peter Collinson, that Peter's early letters abound with oft repeated and emphatic cautions to his friend John, not to allow these delightful studies of nature, equally cherished by them both, to interfere with attention to the duties of life, industry in business, economy, and care of his private affairs; and that the result should have been, while the London merchant, the prudent counsellor, was successful in business for a time, amassed a large estate, and to the last was highly and universally esteemed for substantial virtues, fell himself into the enticing snare against which he had so anxiously guarded his friend, leaving an estate greatly dilapidated when he died; while John Bartram held on to the last, with his industries, economies, and care of his estate. The arrears of his claims upon Peter Collinson had accumulated to an amount which gave great anxiety to the son who succeeded him, and drew out the melancholy fact, that his father had felt himself obliged, at over seventy years of age, after a life so much devoted to the public, to ask a small pension from the king, and that it had been denied him.

Our authority for what Linnæus said of Bartram is Francis Lieber. Such applause from one so much applauded, must of itself cause naturalists to look with intense interest into memorials of his life and doings. All liberal and-inquiring minds must be interested to know something of his biography, of whom one of the highest compliments which could be paid to so good a man as Peter Collinson by the just and discriminating Fothergill, was to say, that he made John Bartram what he was.

He was of the third generation after those who came over with Penn, and settled as agriculturists upon the banks of the Delaware along side of their predecessors, the Swedes, and where the two races have since mingled their blood and extended themselves, constituting now an industrious, virtuous and thriving population, with agricultural improvements, and a general state of worldly prosperity arising from this source, unsurpassed in any quarter of the Union. In his early career he was cotemporary with James Logan, who was himself a distinguished naturalist, and one of the first to appreciate the great idea of Linnæus; having tested by his own experiments, 
early, the truth of the sexes of plants. This learned and eminent man took a deep interest in John Bartram's devotion to natural science, and helped to give him character with Peter Collinson, and make him known to the savans abroad, to whom, at that time, an opportunity to correspond with a great natural botanist in the new world was of inestimable value. He was also, as we have already seen, cotemporary with Benjamin Franklin, who contributed in no small degree with Logan and Collinson to extend his reputation abroad. Indeed it may with truth be said that there was scarcely an individual in this country, after Logan and Franklin, who made himself more highly esteemed in Europe in the age in which he lived, than this Pennsylvania farmer.

The ancient county of Chester, adjoining Philadelphia on the south and west, was originally settled by the countrymen of Linnæus, and their descendants still flourish in the same region. When William Penn came over, many of his agricultural friends, with ample means and the characteristic virtue of thrift, located themselves, as before observed, in this county. But little more than a century and a half has rolled by, and there are now near a hundred houses of worship of the society of Friends in what was once Chester county; the county of Delaware having since been divided off from it on the south-east. This county gave birth to John Bartram and Humphry Marshall, and it was fit and proper that their natal soil should also produce for them a memorialist. Its capital town, from whence this work originates, is not a little signalized for its attention to botanical and horticultural pursuits. It has its Hall of the Cabinet of Natural Science and its Horticultural Hall, with extensive collections in the various departments of the works of nature. A taste for the study of the natural sciences, and special delight in the cultivation of trees, plants, fruits and flowers, would seem to be indigenous with the dwellers in that region. Their anniversary horticultural exhibition is a great gala day, bringing together thousands of the substantial citizens, with wives and children, their countenances lighted up with a smile which indicates the joy they take in it.

Bartram and Marshall were farmers, and the sons of farmers; they cultivated their own acres and built their own houses 
"with their own hands." The woodcuts of these houses as they now stand, which we see in Dr. Darlington's book, give some idea of the substantial and the comfortable which prevailed among Friends in the construction of their dwellings, in Chester county, a hundred years gone by. In mind, and in reputation, these sons of the soil and distinguished naturalists were also self-cultivated, self-educated men. Brought into intimate contact, by their daily avocations, with some of the most interesting works of nature, they did not close their eyes, as so many of us do, to the beauties and wonders by which they were surrounded. They regarded with scrutinizing curiosity the springing blade, the opening bud, the blooming flower, the ripening fruit, with which nature seemed alive in all but infinite varieties. They soon found it to be among their highest earthly pleasures to make themselves acquainted with the secrets, principles, and unnumbered varieties of the system, in this department of nature's wonder-workings. The enthusiasm with which respectively and successively they devoted themselves to the study, and the industry and perseverance with which they followed it, was accompanied with a modesty, prudence, worth, and other sterling virtues, which must endear their memory to all who read their lives, and give it a place in the inner shrine of every naturalist. Linnæus, Sir Hans Sloane, Solander, Philip Miller, Gronovius, and Dillenius were among the correspondents of John Bartram. Dr. Fothergill, Sir Joseph Banks, and Dr. Franklin were among those of Humphry Marshall.

No two men in this country ever contributed so much to the botanical treasures of England, nor anything like so much to the chief ornaments of her grounds.

In proof of Bartram's genius, some letters of this self-educated Pennsylvania farmer may be cited, which are scarcely surpassed in beauty of thought and style by anything in our language.

The following passage from the work before us, teaches us how naturalists give their hearts to each other:

In a letter from * Dr. Garden to Linnæus, dated Charleston,

* In Nichols's Literary Anecdotes, there is a notice of the celebrated Dr. James Parsons, of the last century, where we find in an Eloge by Dr. 
South Carolina, March, 15, 1755, that gentleman says: "When I came to New York, I immediately inquired for Coldenhamia, the seat of that most eminent botanist, Mr. Colden. Here, by good fortune, I first met with John Bartram, returning from the Blue Mountains, as they are called. How grateful was such a meeting to me! And how unusual in this part of

Maty, a list of the intimacies which he formed with " some of the greatest men of his time," which concludes with the names of Corurnson and G "the most distinguished rank in science," $D_{R}$. G ARDEN $_{\text {is }}$ placed along side of Buffon, Beccaria, \&c., by Nichols himself, who adds in another Note.: "Mrs.Parsons had several letters subscribed by the illustrious names above mentioned ; and one from Dr. Garden shall be here inserted." The letter is then given at length. Such a selection was a high compliment to this name, and as the work in which it appears is rarely to be met with here, some extracts are presented, which speak of Colden, Clayton and Bartram.

It is dated-CharLes Town, South Carolina, May 5th 1755.

"It is now about three years and a half since $I$ first arrived in South Carolina, where I have practiced Pliysic ever since, and employed every spare hour in Botany; but my progress has been much retarded for want of the proper books and assistance. There is only my learned and ingenious friend, the honourable Dr. Bull, who knows the least iota of Botany or any part of Natural History here, which, with my small Botanical Library, (which only consisted of Tournefort, Ray, and Lin. Fund. Botan. with the Flora Virgin. Gron.) was a great hindrance and loss to a beginner. I have lately had a copy of all Linnæus's works, except the late performance of the species plantarum, which $I$ have only just heard of in a letter from a German correspondent. This last year I was obliged to leave Carolina, and go to the Northern Colonies, in search of a cooler and freer air, on the account of health;"- "In the Province of New York I met with the Honourable Cadwallader Colden, a truly great Philosopher, and very accurate and ingenious Botanist; as his Philosophical performances, and his 'Genera Plantarum' published in the 'Acta Upsaliensa.' witnoss.

"Mr. Clayton in Virginia, and John Bartram in Pennsylvania, are the only Botanists or Naturalists that I know of, besides Mr. Colden, on the Continent. And I doubt not that you are well acquainted with the character and genius of both these men. Mr. Bartram is certainly a most surprising man, who, without any assistance of conversation or of books (he understands a very little Botanical Latin) should have arrived at so great a knowledge of plants, especially in a systematical way. It is a great pity that he does not understand Mr. Loefling's Dissertation on Gems: for I am fully persuaded he is amongst the best qualified men to imBude? 
the world! What congratulations and what salutations passed between us! How happy should I be to pass my life with men so distinguished by genius, acuteness, and liberality, as well as by eminent botanical learning and experience ! Men, in whom the greatest knowledge and skill are united to the most amiable candour,

\section{Animce, quales neque candidiores \\ Terra tulit.'}

Such an estimate of Bartram, and such a report of him to the great master of the science in which they all rejoiced, is confirmed by the following letter, which bears date in 1762, and shows that their kind feelings were reciprocal. If there is anything to surpass it in our language, it has not met our eye. The letter is from John Bartram to Dr. Garden.

"My dear worthy friend, I am much affected every time that I read thy pious reflections on the wonderful works of the omnipotent and omniscient Creator. The more we search and accurately examine his works in nature, the more wisdom we discover, whether we observe the mineral, vegetable, or animal kingdom. But, as I am chiefly employed with the vegetable, I shall enlarge more upon it.

"What charming colours appear in the various tribes, in the regular succession of the vernal and autumnal flowers-these so nobly bold, those delicately languid! What a glow is enkindled in some, what a gloss shines in others! With what a masterly skill is every one of the varying tints disposed! Here, they seem to be thrown on with an easy dash of security and freedom; there, they are adjusted by the nicest touches. The verdure of the empalement, or the shading of the petals, impart new liveliness to the whole, whether they are blanded or arranged. Some are intersected with delicate stripes, or studded with radiant spots; others affect to be genteelly powdered,

prove that part of the science. How often have I been pleased, delighted, and instrueted by many of his lively and strong natural thoughts on gems, as to their structure, use, time, and properties! I shall not detain you longer, but again beg leave to request the favour of your correspondence, and your forgiveness for this trouble. I am, with great esteem, Sir, your most obedient and very humble servant,

Alexander Garden. 
or neatly fringed; others are plain in their aspect, and please with their naked simplicity. Some are arrayed in purple; some charm with the virgin's white; others are dashed with erimson; while others are robed in scarlet. Some glitter like silver lace; others shine as if embroidered with gold. Some rise with curious cups, or pendulous bells ; some are disposed in spreading umbels, others crowd in spiked clusters; some are dispersed on spreading branches of lofty trees, on dangling catkins; others sit contented on the humble shrub; some seated on high in the twining vine, and wafted to and fro; others garnish the prostrate, creeping plant. All these have their particular excellences; some for the beauty of their flowers ; others their sweet scent; many the elegance of foliage, or the goodness of their fruit; some the nourishment that their roots afford us; others please the fancy with their regular growth; some are admired for their odd appearance, and many that offend the taste, smell, and sight, too, are of virtue in physic.

"But when we nearly examine the various motions of plants and flowers, in their evening contraction and morning expansion, they seem to be operated upon by something superior to only heat and cold, or shade and sunshine; such as the surprising tribes of the sensitive plants, and the petals of many flowers shutting close up in rainy weather, or in the evening until the female part is fully impregnated: and if we won't allow them real feeling, or what we call sense, it must be some action next degree inferior to it, for which we want a proper epithet, or the immediate finger of God, to whom be all glory and praise." $* \quad * \quad * \quad * \quad * \quad * \quad *$

"I don't dwell so long on the vegetable kingdom, as though I thought the wisdom and power of God were only manifest therein. The contemplation of the mineral, and especially the animal, will equally incline the pious heart to overflow with daily adorations and praises to the grand Giver and Supporter of universal life. But what amazing distant glories are disclosed in a midnight scene! Vast are the bodies which roll in the immense expanse! Orbs beyond orbs without number, suns beyond suns, systems beyond systems, with their proper inhabitants of the great Jehovah's empire, how can we look at these without amazement, or contemplate the Divine Majesty that 
rules them, without the most humble adoration? Esteeming ourselves, with all our wisdom, but as one of the smallest atoms of dust praising the living God, the great I AM."

The promptings of this beautiful effusion will be better understood perhaps by here perusing one or two extracts from Dr. Garden's prior letters to him :

"How eminently happy are those hours, which the humble and philosophic mind spends in investigating and contemplating the inconceivable beauties and mechanism of the works of nature; the true manifestations of that supremely wise and powerful Agent who daily upholds and blesses us.

"May that Fatherly Being continue to enlighten your mind, till that hour come, when the parting of this veil will lay before your eyes a new and more glorious field of contemplation, and still more unutterable sights of bliss."

Dr. Garden had before written to him in these words:

"I rejoice with you, on your increasing collection of these curious productions of the all-wise hand of our omnipotent Creator. May your soul be daily more filled with an humble admiration of his works, and your lips exercised in his praise."

"When this scene of things passes away, and the great and first Author of all leads us to fields of a more rich and fertile clime, there shall we proceed with fresh vigour and enlarged faculties to view him nearer, worship and adore more strongly, and live more willingly within the pale of universal love. How great is our God! How wonderful are his works, sought out of all them that take pleasure therein. Your letters, particularly, give me pleasure. They always contain something new and entertaining on some new-discovered work of God."

We now cite some passages from the correspondence, to show how Peter Collinson helped John Bartram, and was in truth the great means whereby he became so distinguished as to be "the greatest natural botanist in the world." Peter Collinson's first published letter is dated in 1734 . In 1736 , we find this paragraph: "Thy kind neighbour, James Logan, is so good as to order me to buy thee Parkinson's Herbal. He has shown a very tender regard for thee, in his letter to me. It may look grateful, every now and then, to call and inquire 
after thy friend Logan's welfare. He is a great man in every capacity, and for whom I have the highest value."

About the same time James Logan writes thus to the young but rising naturalist:

"Friend J. Bartram-Last night, in the twilight, I received the enclosed, and opened it by mistake. Last year Peter sent me some tables, which I never examined till since I last saw thee. They are six very large sheets, in which the author * [Linnæus] digests all the productions of nature in classes.

"His method in the vegetables is altogether new, for he

* In a letter to Col. Byrd, a distinguished citizen of Virginia, in 1739, Bartram says:

"I have this spring made several microscopical observations upon the male and female parts in vegetables, to oblige some ingenious botanists in Leyden, who requested that favour of me, which I hope I have performed to their satisfaction, and as a mechanical demonstration of the certainty of this hypothesis of the different sex, in all plants that have come under my notice.

* * * * *

* * * I have made several successful experiments, of joining several species of the same genus, whereby I have obtained curious mixed colours in flowers, never known before; but this requires an accurate observation and judgment, to know the precise time.

I hope by these practical observations to open a gate into a very large field of experimental knowledge, which, if judiciously improved, may be a considerable addition to the beauty of the florist's garden."-Mem. p. 315 .

Writing to Philip Miller in 1755, Bartram thus refers to this subject.

"I take thy offer very kindly, to assist me in understanding Linn sus's system, which I am acquainted with in some degree; having several books of his setting forth, which Dr. Grovovius, niy good friend, hath sent me; and Mons. Dalibard sent me his Catalogue of plants growing near Paris; and Hill hath nearly translated Linseus's Characters. But I find many plants that do not answer to any of his Genera, and are really new.

I have an account that he hath published, lately, two books containing all our North American plants which KALM observed, when he was with us. I showed him many that he said were new Genera, and that LiNNous must make many alterations, when he was by him more truly informed of their true characters, as I should soon see when they were printed. I long to see these books, - to see if they have done me justice, as KaLM promised me. Dr. Grovovius promised to send them to me, as soon as they came to his hand."-Ib. p. 37T. 
takes all his distinctions from the stamina and the styles, the first of which he calls husbands, and the other wives.

"The performance is very curious, and at this time worth thy notice. I would send it to thee, but, being in Latin, it will want some explanation, which after I have given thee, thou wilt, I believe, be fully able to deal with it thyself, since thou generally knows the plants' names. If thou wilt step to town to-morrow, thou wilt find me there with them at E. Shippen's, or J. Pemberton's, from twelve to three. I want also to say something further to thee, on microscopical observations.

"Thy real friend,

"Stenton, 19th of June, 1736."

"J. LOGAN.

This letter furnishes the evidence that Peter Collinson was the first one to call Logan's attention to the great discovery of Linnæus, and put the means in his power which led him to those experiments whereby he tested its truth, and made the publication which added so greatly to his own fame.

The next year Peter concludes a letter to his friend thus:

"Now, dear John, I have made some running remarks on thy curious letter, which contains so many fine remarks, that it deserved to be read before the Royal Society; and thee has their thanks for it, desiring thee to continue thy observations, and communicate them. I say make no apology. Thy style is much beyond what one might expect from a man of thy education. The facts are well described, and very intelligible."

In another, the same year, he says to him:

"Thy map of Schuylkill is very prettily done, and very informing; now I can read and travel at the same time. Lord Petre has seen it, and is much pleased with that and thy journal; one helps to illustrate the other. I intend to communicate it to a curious map-maker; it may be of use to him in laying down that part of the river Schuylkill undescribed."

March 3, 1741-2.-He writes:

"Dear friexd JoHs:-By our good friend Captain Wright, I have sent Sir Hans's kind present, of his Natural History of Jamaica, in two volumes. These I have put in a box I had macie on purpose for them, and directed it on two places for 
thee; and with it I sent on board, in a canvass wrapper, a large bundle of paper, a present from Dr. Dillenius, which, I think, will furnish thee with paper for specimens, and for seeds, for thy life time. It is fine Dutch paper, and very fit for such purposes, because it will bear ink."

(Then, after cordially thanking him for divers rare and curious objects of Natural History, just received, a bare reference to each of which occupies two printed pages, he goes on,)

"I thank thee for thy curious present of thy map, and thy draught of the fall of the river Owegos (?). I was really both delighted and surprised to see it so naturally done, and at thy ingenuity in the performance. Upon my word, friend John, I can't help admiring thy abilities in so many instances. I shall be sparing to say what more I think. A man of thy prudence will place this to a right account, to encourage thee to proceed gently in these curious things, which belong to a man of leisure and not to a man of business. The main chance must be minded. Many an ingenious man has lost himself for want of this regard, by devoting too much of his time to these matters. A hint thee will take in friendship: thy obliging, grateful disposition may carry thee too far. I am glad and delight much in all these things-none more: but then I would not purchase them at the expense of my friend's precious time-to the detriment of his interest and business, (now, dear John, take me right.) I showed them to Sir Hans. He was much pleased. Lord Petre deservedly much admires them; and, indeed, does every one that sees them, when they are told who was the performer.

"All this is writ by rote, or from memory, for I dare not, nay, I cannot, look into my letters; for I have no time to add more, but to tell thee-in the trunk of the Library Company, thee'll find a suit of clothes for thyself. This may serve to protect thy outward man, being a drugget coat, black waistcoat, and shagg breeches. And now, that thou may see I am not thoughtless of thy better part, I send thee R. Barclay's Apolo$g y$, to replenish thy inward man. So farewell."

In a postscript he adds:

"There is a map, and another parcel or two besides for thee, 
and Catesby's books; and Dr. Dillenius will send thee his History of Mosses."

It is but just that we should say, John Bartram's views differed in many respects from those of his friend Collinson, both in his religious and political creed, and this is perhaps the proper place to refer to it.

When Bartram acknowledged the receipt of the last letter and its accompaniments, he concludes thus :

"I am greatly obliged to thee for thy present of a suit of clothes, which just came in the right time; and Barclay's Apology I shall take care of for thy sake. It answers thy advice much better than if thee had sent me one of Natural History, or Botany, which I should have spent ten times the hours in reading of, while I have laboured for the maintenance of my family. Indeed, I have little respect to apologies and disputes about the ceremonial parts of religion, which often introduce animosities, confusion, and disorders of the mindand sometimes body too: but, dear Peter, let us worship the One Almighty Power, in sincerity of heart, with resignation to his divine will, doing to others as we would have them do to us, if we were in their circumstances. Living in love and innocency, we may die in hope."

There are many other passages throughout the correspondence, which indicate that the germ of those seeds which have since rent the society in twain, was cherished by these friends respectively, in opposition to each other, a century past.

John Bartram also seems to have agreed with Logan* as to the necessity of defensive war, while Peter Collinson adhered to strict views of Friends on this subject.

It still remains a study for the casuists, and is worthy of the best thoughts and most profound consideration of the wisest men, whether William Penn's great idea of founding a State, upon the principle of "love to God, and good will to man;" without recourse, under any conceivable circumstances to defen-

* See "A letter from James Logan to the Society of Friends, on the subject of their opposition in the Legislature to all means for the defence of the colony, September 22d, 1741." Article V. of the Collections of the Historical Society of Pennsylvania, Vol. I, No. 1, May, 1851. 
sive war-to all necessary resistance to attack, or assault, could have been carried into effect without such men as James Logan at his right hand, whose principles so far adapted themselves to the actually existing state of things as to do what was necessary to be done, when the alternative came; to die yourself, suffer wives and children, old and young, the brightest and the best, to be cut down and all your human hopes destroyed, or to take the lives of your murderous assailants.

Logan's idea was, "that all government is founded on force," and involves the necessity of defensive war; and he expresses the surprise with which he learned from Penn, on their first voyage to this country, the different views held by his patron the great philanthropist.

Franklin relates a singular anecdote of great point, as having come from Logan himself, detailing an occurrence on this voyage which led to an interchange of views.

Many distinguished individuals conforming to the principles of Friends in other respects, have been of James Logan's mind, in this particular. Of this number may be mentioned, John Dickinson and William Rawle, as well as John Bartram.

But the letter of James Logan, which now first appears in print, we are told was held by the committee of the yearly meeting to which it had been referred "unfit to be read to the meeting."

There were frequent passages between them as to Pitt, of whom Bartram was a great admirer. The following is from Collinson, in 1763 :

"But my dear John, I am sorry to say thou art of that unhappy cast of mind there is no pleasing.

"Look into Pitt's peace, and see what a pitiful figure we should have made when he adopted Montcalm's boundary for our colonies. As Pitt did it, and accepted it, and made it the foundation of his peace-it was glorious! Pray look back and see what slaughter and destruction the Cherokees made (when Pitt's British glory was lost in Germany) on the back settlements of Carolina; but every thing the turn-coat did was glorious with my dear John! He heard all their cruelties, but did not then open his lips to complain. Whilst Pitt was sacrificing thousands 
of the best British heroes to his projects on the coast of France, to gratify his vanity-all was glorious !

"My dear John, take heart, and don't be carried away with reports. Revive thy drooping spirits, and look forward and hope for the best." . . .

"Glorious Pitt so presides in my dear John's mind he is invincible to complaints, except on the sorry peace that hath given so great an empire to Britain!" ...

"I have a great respect for Pitt, and he has his merits; but every thing he did was not glorious, though my friend John thinks so."

But their most remarkable difference of views perhaps-one frequently, fully, and we may say ably discussed between them, was as to our treatment of the Indians. Bartram seems to have felt that their extermination was inevitable upon the approach of civilized man; as much so as that of the beast of the forest, and the most venomous reptilcs ; that they were irreclaimable; incapable of civilization; that all Christian efforts were lost upon them; while Collinson uniformly, earnestly, and perseveringly inculcated opposite views.

All will be interested to see a portion of this correspondence respecting the natives. It will be found curious, interesting, and instructive.

\section{JOHN BARTRAM TO PETER COLLINSON.}

"February 21, 1756.

Dear Peter-We are now in a grievous distressed condition ; the barbarous, inhuman, ungrateful natives weekly murdering our back inhabitants; and those few Indians that profess some friendship to us, are watching for an opportunity to ruin us. And we that are near the city are under apprehensions too from the neutral French, which are sent among us full of resentment and revenge, although they yet appear tolerably civil when we feed them with the best we can afford. They are very fond of their brethren, the Irish and Dutch Romans, which are very numerous amongst us, many of which openly declare their wishes that the French and Indians would destroy us all; and others of them privately rejoice at our calamities. 0 deplorable condition! that we suspect our friend of treachery

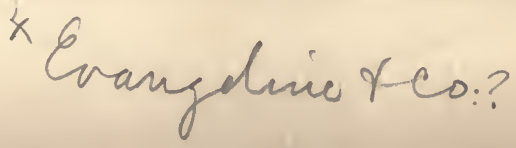


while he is willing to assist us, and can't discover our enemy till it is too late!

"By what we can understand by the reports of our back inhabitants, most of the Indians which are so cruel, are such as were almost daily familiars at their houses, ate, drank, cursed, and swore together-were even intimate playmates; and now, without any provocation, destroy all before them with fire, ball, and tomahawk. They commonly now shoot with rifles, with which they will at a great distance, from behind a tree, fence, ditch or rock, or under the covert of leaves, take such sure aim as seldom misseth their mark. If they attack a house that is pretty well manned, they creep behind some fence, or hedge, or tree, and shoot red hot iron slugs, or punk, into the roof, and fire the house over their heads; and if they run out they are sure to be shot at, and most or all of them killed. If they come to a house where most of the family are women and children, they break into it, kill them all, plunder the house, and burn it with the dead in it; or if any escape out, they pursue and kill them. If the cattle are in the stable, they fire it and burn the stable; if they are out, they are shot, and the barn burnt. If our captains pursue them in the level woods, they skip from trce to tree like monkeys; if in the mountains, like wild goats they leap from rock to rock, or hide themselves, and attack us in flank and rear, when, but the minute before, we pursued their track and thought they were all before us. They are like the angel of death-give us the mortal stroke when we think ourselves secure from danger.

"O Pennsylvania! thou that was the most flourishing and peaceable province in North America, art now scourged by the most barbarous creatures in the universe. All ages, sexes, and stations, have no mercy extended to them." . . .

History does not contain a more graphic description of the character of early Indian warfare. Those amongst us who are disposed to be very severe upon the first settlers in New England for their frequent contests with the natives, and indulge themselves in invidious comparisons, might read this correspondence with profit. The question has two sides; and let us ever remember, with Jeremy Taylor, that severe judgment should begin at home. 
JOHN BARTRAM TO PETER COLLINSON.

September 30, 1763.

Dear PeTer-I have now travelled near thirty years through our provinces, and in some, twenty times in the same provinces, and yet never, as I remember, once found one single species in all after times, that I did not observe in my first journey through the same province. But many times I found that plant the first which neither I nor any person could find after, which plants, I suppose, were destroyed by the cattle. . . . The first time I crossed the Shenandoah I saw one or two plants, or rather stalk and seed of the Meadia, on its bank. I jumped off, got the seed, and brought it home, sent part to thee, and part I sowed myself-both which succeeded; and if I had not gone to that spot, perhaps it had been wholly lost to the world. John Clayton asked me where I found it; I described the very spot to him, but neither he nor any person from him could find it after. 0 ! what a noble discovery I could have made on the banks of the Ohio and Mississippi, if I had gone down, and the Indians had been peaceably inclined, as I knew many plants that grew on its northern branches. But we are at present all disappointed.

I read lately, in our newspaper, of a noble and absolutely necessary scheme that was proposed in England, if it was practicable; that was, to search all the country of Canada and Louisiana for all natural productions, convenient situations for manufactories, and different soils, minerals and vegetables; the last of which I dare take upon myself, as I know more of the North American plants than any others. But this would alarm the Indians to the highest degree. All the discoverers would be exposed to the greatest savage cruelty-the gun, tomahawk, torture, or revengeful, devouring jaws. Before this scheme can be executed, the Indians must be subdued, or drove above a thousand miles back. No treaty will make discovery safe. Many years past, in our most peaceable times, far beyond the mountains, as I was walking in a path with an Indian guide, hired for two dollars, an Indian man met me and pulled off my hat in a great passion, and chawed it all round-I suppose to show me that he would eat me if I came into that country again." 


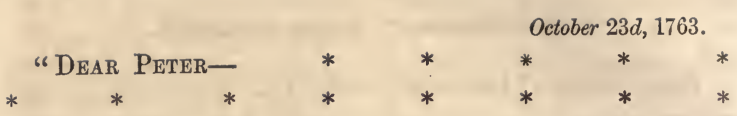

The most probable, and only method to establish a lasting peace with the barbarous Indians, is to bang them stoutly, and make. them sensible that we are men whom they for many years despised as women; until then, it is only throwing away men, blood, and treasure, to make peace with them. They will not keep to any treaty of peace. They all are, with their fathers, the French, resolved to drive the English out of North America. And although some tribes pretend to be neutral friends, it is only with a design to supply the rest with ammunition to murder us. Perhaps now, and only now, is the critical time offered to Britain to secure not only her old possessions, but her so much boasted new acquisitions, in sending us sufficient supplies to repel effectually those barbarous savages."

\section{PETER COLLINSON TO JOHN BARTRAM.}

"Ridgeway House, December 6, 1763.

"I am here retired, all alone, from the bustle and hurry of the town, meditating on the comforts I enjoy; and while the old log is burning, the fire of friendship is blazing-warms my imagination with reflecting on the variety of incidents that hath attended our long and agreeable correspondence.

"My dear John, thou dost not consider the law of right, and doing to others as we would be done unto.

"We, every manner of way, trick, cheat, and abuse these Indians with impunity. They were notoriously jockeyed and cheated out of their land in your province, by a man walking a tract of ground in one day, that was to be purchased of them.

"Your Governor promised the Indians, if they would not join the French, that when the war was over our troops would withdraw from Pittsburg. They sent to claim this promise, but were shuffled off. They resented it, as that fortress was situated on their hunting country.

"I could fill this letter with our arbitrary proceedings, all the colonies through ; with our arbitrary, illegal taking their lands 
from them, making them drunk, and cheating them of their property. As their merciless, barbarous methods of revenge and resentment are so well known, our people should be more careful how they provoke them. Let a person of power come and take five or ten acres of my friend John's land from him, and give him half price, or no price for it, how easy and resigned he would be, and submit to such usage! But if an Indian resents it in this way, instead of doing him justice, and making peace with him, nothing but fire and faggot will do with my friend John! He does not search into the bottom of these insurrections. They are smothered up, because we are the aggressors. But see my two proposals, in the October Gentleman's Magazine, for a peace with the Indians.

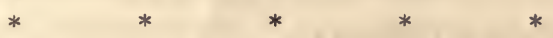

"What a glorious scene is opened in that rich country about Pensacola-if that despised country is worthy thy visitation. But because Pitt did not get it, thou canst not venture there on any pretence! All beyond the Carolinas is forbidden ground. They are none of thy darling Pitt's acquisitions!

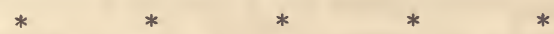

"I hope what I have writ will be read with candour. Our long friendship will allow us to rally one another, and crack a joke without offence, as none was intended by thy sincere friend,

P. Collinson.

"London, January 1, 1763-4.

"I am very thankful to the great Author of my being that I enter the new year in perfect good health and spirits. I heartily wish the like comfortable situation may attend my dear friend and his family.

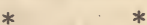

"Thy quick discernment of plants is a knack peculiar to thyself, and is attained by the long exercise of thy faculties in that amusement, and is like the hare finders with us. Some can't discover them if close under their feet; others sec them at a great distance.

"Indeed, my dear John, I must congratulate you on that 
happy discovery of my favorite Meadia. It is really remarkable none should be found since.

"I hear nothing more of that proposal thee mentions; but if there were any real intention of carrying it into execution, no one properer than thyself for Natural History and Botany.

"That the Indians should be alarmed at our sounding or measuring-I don't wonder they should be jealous of our invasion of their property. Every man is tenacious of his native rights, and if you invade their rights, you must take the consequences. Let those be well banged-I may say well hangedthat, by their unjust proceedings, provoked the Indians to hostilities, knowing before-hand their cruel resentments."

Bartram says to Collinson:

* * * * * * * $\underset{\text { March 4, } 1764 \text {. }}{*}$

"I think our Indians received a full value for that cheating walk, and pretended to be fully satisfied with what they received above the first agreement; and as for Pittsburg, they let the French settle and build there; then why may not the English, after they had drove the French out, keep possession of it? And as the Indians have committed such barbarous destruction on our people, we have more reason to destroy them and possess their land than you have to keep Canada. And must all our provinces suffer a prodigious yearly expense, and have thousands of our innocent people barbarously murdered, because some of our traders made them drunk to get a skin cheap?-or an Irishman settles on a bit of their land which they will never make use of? And if we must settle any more land, or any of the branches of the Mississippi, pray say no more about our great British empire, while we must not be a farthing the better for it.

"I should be exceedingly pleased, if I could afford it, to make a thorough search, not only at Pensacola, but the coast of Florida, Alabama, Georgia, and the banks of the Mississippi. I make no difference who got it, if I could but safely travel in it.

"My dear friend, I am so far from taking offence at thy familiar way of writing, that it gives me much pleasure." 
COLLINSON TO BARTRAM.

"March 7, 1764.

* $\quad * \quad$ * $\quad * \quad * \quad * \quad *$

"Is it reasonable to think the Indians will love us, after such a cruel, unprovoked slaughter at Lancaster, \&c.? I hope the authors will be made examples of justice."

* $\quad * \quad * \quad * \quad$ Mill Hill, May 28, 1766.

"In all thy expeditions, didst thee fall in with any Indians? what nation? and how did they behave? Is there any disposition in them to continue in peace and friendship? There is much talk of civilizing them. A good, sensible man, named Hammerer, a foreigner, who was long in London, could not be easy without going to reside among the Cherokees, in order to try to bring them to a sense of moral duties."

What Bartram saw and had to encounter in his botanical excursions throngh western New York at that early day, will be better understood by those who read the "Narrative of a Journey made in the year 1737, by Conrad Weiser, from Tulpehocken to Onondago," lately published by the Pennsylvania Historical Society. After overcoming all but unendurable hardships on his journey, in the months of February and March, upon his arrival among the natives of that then savage frontier, he gives us this account of a conversation with them. "I asked them how it happened that they were so short of provisions now, while twelve years ago they had a greater supply than all the other Indians; and now their children looked like dead persons, and suffered much from hunger. They answered, that now game was scarce, and that hunting had strangely failed since last winter; some of them had procured nothing at all. That the Lord and Creator of the world was resolved to destroy the Indians. One of their seers, whom they named, had seen a vision of God, who had said to him the following words : 'You inquire after the cause why game has become scarce. I will tell you. You kill it for the sake of the skins which you 
give for strong liquor, and drown your senses, and kill one another, and carry on a dreadful debauchery. Therefore have I driven the wild animals out of the country, for they are mine. If you will do good and cease from your sins I will bring them back ; if not, I will destroy them from off the face of the earth.'

"I inquired if they believed what the seer had seen and heard. They answered, yes, some believed it would happen so, others also believed it, but gave themselves no concern about it. Time will show, said they, what is to happen to us ; rum will kill us, and leave the land clear for the Europeans without strife or purchase." p. 17.

Upon another occasion he tells us:

"This was the hardest and most fatiguing day's journey I had ever made; my bodily strength was so much exhausted that I trembled and.shook so much all over, I thought I must fall from weariness, and perish. I stepped aside and sat down under a tree to die, which I hoped would be hastened by the cold approaching night. When my companions remarked my absence, they waited for me some time, then returned to seek me, and found me sitting under a tree. But I could not be persuaded to proceed, for I thought it beyond my power. The entreaties of the old chief and the sensible reasoning of Shikelimo* (who said that evil days were better for us than good, for the first often warned us against sins and washed them out, while the latter often enticed us to sin), caused me to alter my resolution, and I arose."

Peter Collinson enlisted several of his friends to contribute $£ 10$ each, as a yearly stipend, to stimulate, and partially remunerate Bartram for his researches and the treasures he sent them from the new world; and finally had him appointed king's botanist, with a salary of $£ 50$ a year.

The interest expressed by Lord Petre was truly wonderful, and nothing can exceed the mournful outpouring of the heart in a letter which announces the early death of this excellent nobleman, and which, for the pathos of its allusion to the parting, is worthy to be placed along side of Dr. Garden's illustration of how naturalists become attached to each other on their first acquaintance. But the letter must speak for itself.

* Father of the Logan whom Jefferson has made memorable. 
"London, July 3d, 1742.

"OH ! Friend JoHs :-I can't express the concern of mind that I am under, on so many accounts. I have lost my friend, my brother. The man I loved, and was dearer to me than all men-is no more. I could fill this sheet and many more; but oh! my anxiety of mind is so great, that I can hardly write; and yet I must tell thee, that on Friday, July 2d, our dear friend Lord Petre was carried off by the small pox, in the thirtieth year of his age. Hard, hard, cruel hard, to be taken from his friends, his family, his country, in the prime of life; when he had so many thousand things locked up in his heart, for the benefit of them all-now lost in embryo.

"I can go no further, but to assure thee that I am thy friend. P. Collinson.

"All our schemes are broke.

"Send no seeds for him, nor the Duke of Norfolk; for now, he that gave motion is motionless-all is at an end.

"As I know this will be a great disappointment to thee, if thou hast a mind to send the seeds, as was ordered for Lord Petre and Duke of Norfolk on thy own account and risk-I will do what I can to dispose of them. The Duke of Norfolk shall have the preference; but there is no obliging him to take them, as I had not the order from him, but from Lord Petre.

"Send those for the Duke of Richmond and P. Miller.

"Lord Petre was a fine, tall, comely personage-handsomehad the presence of a prince; yet was so happily mixed, that love and awe were begot at the same time. The affability and sweetness of his temper were beyond expression, without the least mixture of pride or haughtiness. With an engaging smile he always met his friends. But oh! the endowments of his mind were not to be described. Few or none could excel him in the knowledge of the liberal arts and sciences. He was a great mechanic as well as a great mathematician; ready at figures and calculations, and elegant in his tastes.

"In his religious way,* an example of great piety; his morals of great temperance and sobriety; no loose word, or

* Lord Petre belonged to the Roman Catholic Chureh. 
double entendre, did I ever hear-(this is something of the man.). For his virtues, his excellencies, and his endowments, I loved him, and he me, more like a brother than a friend."

Thirty years after their correspondence had commenced, Peter Collinson writes thus to John Bartram :

"I have pleasure upon pleasure beyond measure, with perusing my dear John's letters of Oetober 31st, with the rare plants in Eden."

"Think, my dear John, with what amazement and delight I, with Dr. Solander, surveyed the quire of specimens. He thinks near half are new genera. This will enrich the fountain of knowledge." __ "But what surprises us most, is the Tipitiwitchet Sensitive. It is quite a new species, a new genus." (Dioncea muscipula.)_-"

Again soon after-

"I am glad, my dear John, I can send our friend Solander's catalogue of thy last curious collection of specimens. There are wonderful things amongst them, especially the Sensitive, Empetrum," \&c. * * * * * * * *

"They enrich our knowledge, and anticipate our pleasures, and give us a good idea of the riches in store, to gratify the botanists of after ages. 0 , botany! delightfulest of all sciences! There is no end of thy gratifications. All botanists will join with me in thanking my dear John for his unwearied pains to gratify every inquisitive genius. I have sent Linnæus a specimen, and one leaf of Tipitiwitchet Sensitive : only to him would I spare such a jewel. Pray send more specimens. I am afraid we can never raise it-Linnæus will be in raptures at the sight of it."

Again under date of August 4th, 1763 :

"My garden, like thine, makes a glorious appearance; with fine long-spiked purple Ononis; with the all-spice of Carolina [Calycanthus floridus, L.,] abundantly in flower-spreading its perfumes abroad; the delectable red-flowering Acacia; my laurel-leafed Magnolia, with its noble blossoms, which will continue for two months or more. The great Rhododendron has been glorious beyond expression; and before, I told thee of the mountain Magnolia, and the surprising flowers of the red and yellow Sarracenia. Thus, my dear John, thou sees I am 
not much behind thee in a fine show, but when thy Eden plants flower, I shall not be able to bear the report of them."

"Consider, my dear John, what pleasure I feel now.

I can give thee an order for a ten guinea box, for young Lord Petre. Little did I think, when I gave thee the first like order for his valuable father in $\mathbf{1 7 3 5}$ or $\mathbf{1 7 3 6}$, that I should live to give the like for his son. It may be truly said that the spirit of Elijah rests on Elisha, for he began this year with a box of thy seeds."

In acknowledging this, Bartram thus expresses himself :

"I am heartily glad that young Lord Petre is possessed of the botanical taste of his father. I wish he may resemble him in virtue. I have intended to inquire after him and his mother in every late letter. The pear raised from her seed hath borne a number of the finest relished fruit. I think a better is not in the world."

In a note to which, the editor informs us, "This tree, known as 'Lady Petre's Pear tree,' is still (1848) flourishing at the Bartram garden, standing close by the house.

Peter Collinson, in 1764, when noticing Bartram's last remark, says : "It has been thy patience to wait, but my pleasure to hear of the delicious pear raised from Lady Petre's seed ; but she, dear good woman, is gone to rest."

In 1765 he makes this announcement:

"I have the pleasure to inform my good friend, that my repeated solicitations have not been in vain. I this day received certain intelligence from our gracious king that he had appointed thee his botanist, with a salary of fifty pounds a year."

These are a few of the many, many specimens of the acts of kindness, expressions of sympathy and admiration, and long. abiding, devoted friendship, which these letters present, holding up Peter Collinson as a pattern for the doers of good in all succeeding ages.

"He was one of the earliest and most constant correspondents of Linnæus, and was highly distinguished in the circle of naturalists and antiquaries in London, for nearly half a century."

An interesting little tract giving some accounts of him, 4 
which appeared soon after his death, and is generally ascribed to Dr. Fothergill, gave rise to a correspondence with Dr. Franklin as to its authorship.

The following passage is from one of Franklin's letters"If we estimate the goodness of a man by his disposition to do good, and his constant endeavours and success in doing it, I can hardly conceive that a better man has ever existed ;"speaking of him $\dagger$ who was first to sound Peter Collinson's praises, when he went from earth to heaven.

But even Peter Collinson, with Dr. Fothergill at his right hand, could hardly have made Bartram what he became, but for what he says of himself ;

"I had always since ten years old, a great inclination for plants, and knew all that I once observed by sight, though not their proper names, having no persons or books to instruct me ;" and, for what his son says of him-" $\mathrm{He}$ had all, or most of the education that could at that time be acquired in our country schools; and whenever an opportunity offered, he studied such of the Latin and Greek grammars and classics as his circumstances enabled him to purchase, and always sought the society of the most learned and virtuous men." The son also says, that the intimate friendship and correspondence between his father and Peter Collinson continued fifty years, although the letters brought to light by Dr. Darlington, cover a period of but thirty-four. He purchased the place which his garden has made classic ground, at sheriff's salein 1728, and built the house still standing there in $\mathbf{1 7 3 1 .}$

Bartram's garden has been an object of interest the world over, for a century past. Unique in its character and extent on this side the water, it became early somewhat famous. It was not only attractive to naturalists, but was generally visited by strangers who came to Philadelphia to spend any time, and frequently by the passing traveller. Its precise location is on the west bank of the Schuylkill, a little below Gray's Ferry, an intervening bluff hiding it from the Woodlands, originally retired from the great public road leading south. Now, indeed, the

* See a fuller sketch of his life and character in the Appendix.

$\dagger$ Dr. Fothergill. 
railroad passes through a deep cut directly in rear of the house. We rejoice that since the appearance of these memorials it has fallen into hands which, as far as possible, will preserve what may keep alive its interesting memories. It was once feared, that in the changes of time, and chance, and fortune, this classic spot, where for many a long year things curious and beautiful in nature were cultivated, trained, and developed by a master hand, might become desecrated by occupation for the business purposes of every day life ; and that not being able to preserve both "the beautiful and the useful," we should have had to console ourselves that our own Franklin had classic authority for placing "the useful" first, had we been condemned to see Bartram's Garden transformed to a coal yard. Philadelphians may thank Dr. Darlington's book, probably, for the escape.

Whoever visits the Bartram garden now, let him be sure to inquire for the "Lady Petre's pear tree;" and when he next attends the anniversary exhibition of the Pennsylvania Horticultural Society, let him remember to look at a specimen of its fruit which he will certainly find there. The president, secretary, or the second of the committee on fruits, while they live, will as certainly one of them be at hand to point out this product of a tree from seed planted more than a century ago, of fruit grown on the grounds of a noble horticulturist who was also a horticulturist nobleman in England, in Bartram's garden, on the banks of the Schuylkill, by the agency of Peter Collinson.

We have referred to three officers of an existing society in connection with reminiscences of their distinguished predecessors in horticulture, because we know of no others who hare done more to promote and extend the usefulness of this society; and we know of no society which has added more to the worldly comforts, the cheerfulness and happiness of all, in a city famed for its abounding good things, and more especially for the number of institutions, where "wisdom dwells with prudence, and finds out knowledge of witty inventions" to do good.

We had intended giving a passage or two from Dr. Fothergill's letter, on the death of his friend, but our prescribed limits 
forbid.* For an opportunity to do this, copying from the original edition, we are indebted to that indefatigable and accomplished naturalist, Dr. Francis Boott, $\dagger$ of London, who, combining American sympathies from his birth among us, with

* One of these passages is here given:

"Planting, he used to say, and gardening, supply a fund of entertainment, the most lasting and reasonable of any occupation in this life, pleasures not to be purchased. The trees which we ourselves have planted, the fruits we have raised, the plants we have cultivated, seem to be like our children, a kind of new creation. Their shade, their taste, their fragrance and their beauties, affect us with a richer repast than any other. What a pleasing scene, would he observe, lies open to a young man of fortune devoted to such amusements! Each succeeding year produces new shades, other fruits, fresh beauties, and brings besides, most certain profit. To behold the rising groves, barrenness made fertile, our country improved, ourselves made useful and happy, and posterity enriched! When on this favorite subject, a very natural expression often cscaped him, that he seldom knew a man possessed of a taste for such pleasures, who was not at the same time temperate and virtuous. And indeed he had a right to make the observation; for he had the satisfaction of reckoning among his most intimate friends, men of the most amiable and unblemished character, in all stations, parties, and distinctions."

"The quantities of new seeds he received from America not only supplied his own garden with every thing that was curious in that region but furnished him with the means of procuring others in exchange from other parts of the globe."

† Since this article was commenced, we came across, at the Philadelphia Library, unlooked for, in a volume labelled "Pamphlets on Ethnology, \&c.," a work with this title page- "Hortus Collinsonianus. An account of plants cultivated by the late Peter Collinson, Esq., F. R. S., arranged alphabetically, according to their modern names, from the catalogue of his garden, and other manuseripts. Not Published. Swansea: Printed by N. C. Murray and D. Rees, MDCCCXLIII." Its prefaco signed L. W. Dillwyn, Sketty Hall, March 8, 1843, in a full and interesting account of the work, gives us the following facts. "The gardens at Peckham and Mill Hill had attained such a high celebrity, that a publication of Mr. Collinson's Catalogue appears to have been called for by some of the most distinguished naturalists, and the reason for his noncompliance with their wishes is thus given in a letter of his, dated May 12, 1756, to his friend Linnæus:- 'You must remember I am a merchant, a man of great business, with many affairs in my head and on my hands. I can never pretend to publish a catalogue of my garden, unless I had one of your ingenious pupils to digest or methodize it for me. It only serves now for my own private use.' " See Sir J. E. Smith's Correspondence of Linnæus, Vol. 1. p. 39. 
intimate relations to the many eminent lovers of nature around him, since this correspondence appeared, has furnished evidence of an intense desire to bring to light all that pertains to one who did so much good in his day and generation on both sides the water, and made so little noise in doing it.

We hope to be excused for indulging in so many extracts, if the reader shall find them give reality to the idea of the great and good John Fothergill, that Peter Collinson made John Bartram what he was; and if they shall lead more people to know than knew it before, that this Pennsylvania gardener of the London merchant's training, was, himself, a great man, in other respects, besides being the greatest natural botanist of his time.

He closes his prefatory remarks with the copy of a memorandum, to which Mr. Collinson had added his signature in 1763.

"I often stand with wonder and amazement when I view the inconceivable variety of flowers, shrubs, and trees, now in our gardens, and what were there forty years ago; in that time what quantities from all North America have annually been collected by my means and procuring, and for some years past a great variety of seeds are brought from China, and many fine plants raised; the China Mulberry I first raised, and from Siberia many curious shrubs and flowers. Very few gardens, if any, excel mine at Mill Hill, the rare exotics of which are my delight."

The horticulturist will find himself amply repaid by looking over this rare and curious, "not published" work, which he will find bound up with the pamphlets on Ethnology, in the Philadelphia Library, as stated. But where did it come from, and how did it get there? We have before referred to the interest awakened by Dr. Darlington's late work in England. One of the many interesting tokens of this was the reception by the author, from L. W. Dillwyn, through the agency of Dr. Boott, of five copies of the Hortus Collinsonianus, one of which Dr. Darlington presented to the Philadelphia Library. These are the only copies, probably, to be found here.

In connection with this subject, it should also be stated, that the letterbook of James Logan, containing copies of many letters to Peter Collinson, is still extant, and a large file of the original letters of this prince of horticulturists in his day, is carefully preserved among the archives of the Logan family. Let us hope that some gifted one may yet arise, who will do more justice than has yet been done to each of these distinguished names. 


\section{APPENDIX.}

IT should have been observed in the notice of Dr. Darlington's work, that there is prefixed to the letters of each of John Bartram's and Humphry Marshall's distinguished correspondents, a condensed but careful, authoritative and interesting sketch of their respective lives and eharacters. For that of Peter Collinson, Dr. Fothergill's letter, and the Linnæan correspondence by Sir James Edward Smith, are referred to as his leading authorities. It has been suggested that it might be gratifying to those who take a lively interest in Peter Collinson's history and character, to append to this edition, a brief sketch of his Biography; and also to add the history of his descendants, to the present time. This last has been furnished to Dr. Darlington at his request, by the great-grand-daughter, Miss Anna Maria Collinson, in a letter to him, dated Leamington, Warwickshire, England, May 14, 1850, with which we have been kindly favoured.

We learn from the letter published soon after his death, usually ascribed to Dr. Fothergill, and re-published as such by Dr. Lettsom in his edition of Fothergill's works*, that the family of the Colurnson's is of ancient standing in the North : Peter and JAMEs were the great-grand-sons of Peter Collinson, who lived on the paternal estate ealled Hugal Hall, or Height of Hugall, near Windermere Lake, in the parish of Stavely, about ten miles from Kendal, in Westmoreland.

Peter was born January 28, 1693-4, in a house opposite to Church Alley, St. Clement's Lane, Lombard street, London. He resided for many years at the Red Lion, on Grace Church street, where as a wholesale woollen draper, in company with his brother James, he accumulated a handsome estate. In 1724, he married Mary, the daughter of Michael Russeld, Esq., of Mill Hill, Hendon. The wife died in May, 1753, leaving him a son MichaEL, and a daughter MARY, married to the late JoHN CAToR, Esq., of Beckenham, Kent. Both inherited many of the good qualities of their father, but Michael is said to have allowod his political feeling to carry him away when the war broke out with this country, even to the undervaluation of his father's most intimate friend, Dr. Fothergill, and extending to both

\footnotetext{
* Entitled "Some Account of the late Peter Collinson, Feliow of the Royal Society, and of the Society of Antiquaries in London, and of the Society of Berlin and Upsal. In a letter to a friend, 1770."
} 
Dr. Franklin and John Bartram.* Peter Collinson's attachment to Natural History, led him early to make a collection of dried specimens of plants, and he availed himself of his ready access to the best gardens around London. He became intimate with the most eminent Naturalists of his time-and was one of the few who visited Sir Hans Sloan, at all times familiarly; a firm friendship having been early established between them which lasted while they lived. There were but few articles in that superb collection, now the British Museum, commenced by his friend, with which he was not familiar. He was elected a Fellow of the Royal Society in 1728, and became one of the most diligent and useful members. While unremitting in his attention to business, he extended his correspondence upon Natural History, and all matters connected with the arts and sciences, the world over. Such was his diligence and economy of time that he never appeared to be in a harry, while he maintained this extensive correspondence with great punctuality, and laid so many of the learned and ingenious under obligations to him, in distant parts of the globe, by acquainting them with the discoveries and improvements in Natural History around him, that he received like information from them in return. Cadwalader Colden, Esq. of New York, and Dr. Franklin and James Logan, of Philadelphia, as well as John Bartram, were among his particular, and most valued correspondents. His aid to the Philadelphia Library was extended, in a similar manner, to many others in the vicinity; and was promotive of widely extended and lasting good, which entitle his name to our grateful remembrance, and secure to Dr. Darlington many thanks for bringing it vividly to mind. During the residence of Linnæus in England,

* It is but just to add the folloviny testimonial by his son.

"At Sproughton Church, near Ipswich :

"This monument is erected

by Charles Streynsham Collinson, Esquire,

to the memory of his father

Michapr Courvsos, Esquire,

late of the Chantry in this parish, and also

of Hendon in the County of Middlesex;

who died the 11th of August, 1795, aged 67 years

He was distinguished for his knowledge of Natural History,

And for the attention he gave to botanical subjects in particular.

From-his generally well-informed mind and polished manners,

his compsny was much esteemed by persons of the first eminence;

And he endeared himself to his more immediate connections. by his

benevolence and liberality.

The enjoyment of the latter part of his Hfe was greatly interrupted by a series of painful disorders, which he sustained

with'much exemplary resignation and fortitude." 
he contracted a close intimacy with him, which continued a life long, and abounded in the reciprocation of kind offices. As an Antiquarian, he was not less eminent and distinguished.

His first improvements, and collections in Horticulture were at Peckham, in Surrey ;* here they became extensive and very interesting. In 1749, when he removed to Ridgway House at Mill Hill, he began the transplanting of them, which occupied him for two years. $\mathrm{He}$ was sometimes despoiled of these treasures so near his heart, but always bore his loss patiently, while he strove to supply their place.

"While in the country he spent most of his time in his garden, taking care of the trees and plants, and observing the operations of nature : he was exceedingly fond of fruit, and a perpetual admirer of flowers, always having them in his house, from the early snow-drop to the autumn cyclamen." $\dagger$

The Hortus Collinsonianus, prepared and printed by L. W. Dillwyn, before alluded to, will fully illustrate his habits in this respect, and well repay diligent and close perusal by every lover of horticulture.

His person was rather short than tall; he had a pleasing and social aspect; was of a temper open and communicative, capable of feeling for distress, and ready to relieve and sympathise. Excepting some attacks of the gout, he enjoyed, in general, perfect health, and great equality of spirits, and had arrived at his 75th year; when, being on a visit to Lord Petre, for whom he had a singular regard, he was seized with an attack, which, baftling every attempt to relieve it, proved fatal, on the 11th of August, 1768. $\$$

For the following letter, from Mr. Thomas Collinson,* a nephew of Peter Collinson, addressed to Dr. Ducarel, giving some account of his illness and last hours, we are indebted to "Nichols's Literary Anecdotes of the Eighteenth Century."

* His brother had a garden near him.

† We are indebted for seversl hints snd facts in this notice to a manuscript sketch from the collections of s lady in this clty, illustrative of the mysteries of nature's handiwork, and which we trust may some day see the light.

$\ddagger$ Peter Collinson, born January 14th, 1698-4, | Mary, daughter of Michsel Russell, Esq., died August 11, 1768 . of Mill Hill, died March 28, 1753.

$\begin{aligned} & \text { Michael Collinson, died August 11, 1795. } \\ & \text { aged 67: }\end{aligned}$
.... Mary Collinson,
$\begin{aligned} & \text { Beckenham, Kent, M. P. } \\ & \text { for Callington. }\end{aligned}$

Charles Streynsham Collinson, Esq. High Sheriff of Suffolk, 1801.

Nichols's Lit. An. Vol. 5, p. 362.

* We add a few words on the life and character of this nephew, whose name, stock, early training, and whole life, further illustrate the idea with which this Tribute commences, as to the excellent traits of character resulting from "a life conformed to principles of Friends." We learn from the Gentleman's Magazine, Vol. 73, p. 878, that Thomas Collinson died August 
"The sympathising concern expressed in yours makes me believe the following particulars of my late worthy uncle's illness will not be altogether uninteresting. [A brief account is then given of the painful disease, with which he was attacked, while on a visit at Lord Petre's, whereupon he immediately returned to town.] Doctors Reeves and Russell, Surgeons Crowell and Adair attended him, but all was in vain. On Thursday last, about 20 minutes before two, he quitted this world.

" Through the whole of his disorder he expressed the most cheerful patience and humble fortitade. He told me at first that 'let the event be what it might, he was content: that it was totally indifferent to him whether he was to go then, or to continue four or five years longer.' 'Few men,' he added, ' have enjoyed life more, been more exempt from pain and disease; and now (he subjoined,) it is come so late in life, I am thankful to Providence he has preserved me so long. I cheerfully resign, and am not afraid to die.' No complaint, no murmer was heard. He accepted with the kindest notice all the assistance administered; told us, he submitted to the various medical and chirurgical operations, both, as being his duty, and to give satisfaction to his family : if success attended, it was well; if the contrary, it was also well. Thus the good man took leave of all visibles; he had used them, without abusing them. He had lived pleasantly, usefully, and honourably; might be justly called a friend to mankind, and an unwearied promoter of knowledge in general, and of Natural History in particular. What can humanity have attained to more desirable? so to have lived, and thus to have died. Yet though reason almost forbids, still the feelings of nature compel me to weep."

22d, 1803, in his 77 th year, and that he was a man of intellectual superfority and distinguished worth. "He was not one of the multitude whose passage through life resembles that of an arrow through the air, leaving not a trace behind. In his yonth, by passing much of his time with his uncle PETKR, he formed an acquaintance with many of the scientifio characters of that period; and his mind became impressed with that love of knowledge, and energy in its pursuit, which attended him through a long life, and only ceased with his existence." Then after giving an account of his extensive travels, his many sccomplishments, his varied and extensive knowledge of Nature and Art, and especially of the topography and Structures of Ancient Rome, it is said of him : "His acquaintance with Natural Philosophy was considerable; and in some branches of the mathematles he had attained distinguished eminence. His conversation was uncommonly animated and energetle; his memory most retentive, bringing forward from its rich treasury the most appropriate illustration of the subject. From his society, few retired without improvement, none without pleasure; his lucid and happy mode of commnnicating instruction, especially to young people, was a marked feature in his character; while they eagerly listened, and imbibed the streams of knowledge, they felt rather conferring than re ceiving an obligation, such was the urbanity and fascination of his manners. As an oconomist of his time, few equalled, none surpassed him; its minutest divisions were not suffered to pass away unheeded or nnimproved. To this, his constant habit of registering the transactions of each day materially contribnted; and that which was terminated without some advance in learning or sclence, he considered as lost. These memorande, regularly entered at the close of 
All accounts agree that Peter Collinson left behind him many materials to aid and interest in the study of Natural History. The devotion to Horticulture for the last half century, on both sides the water, and its present refined taste, owe much to his untiring industry and successful exertions in its behalf. Philip Miller, the great London gardener, whose "Gardener's and Botanist's Dietionary," as edited by Martyn, has never been surpassed either in extent of information or accuracy, and which furnishes so large a portion of the contents of all the most valuable recent works on the subject, was his right-hand man and frequent fellow counsellor. The Duke of Richmond of his time, as well as both the Lords Petre in succession "and others of the first rank in life and letters were his friends; and he was continually urging them to prosecute the most liberal improvements."

The portrait of him, by Miller, prefixed to Dr. Fothergill's letter, is said by those of high authority, to be "excellent."

The one preceding this Tribute is copied from it, being selected as the best among five sent over by Dr. Boott, with a very curious and interesting collection of Collinsoniana, gathered and neatly bound up, for the author of the Memorials after their appearance in England. Indeed, many have recently interested themselves to hunt up every thing pertaining to the cherished name and good doings of this most excellent and extraordinary man.

We follow out the suggestion as to his descendants.

the day, throughout a long series of years, form a very extensive and vaiuable collection of facts, respecting both men and things. His applicstion, even at that period of life when, with most indulgence takes place of activity, and intellectual exertions yields to necessary repose, was truly extraordinary. To a new object, or to the renewal of acquaintance with one imperfectly investigated, he applied with all the ardour of youth, but with the perseverance of more mature age. Of the evils and afflictions incident to humanity he experienced a full proportion. On being married to the daughter of $\mathrm{Mr}$. Hinton Brown he became a partner in the banking house of Brown \& $\mathrm{Co}$., the unexpected failure of which closed his prospects of future affluence forever. He declined again entering into bnsiness, preferring the independence of leisure, which enabled him to follow his favourite pursuits in science, to the risk and toil of renewing his fortune, which be felt was not a duty incumbent on him, having only one child, of whom and of his wife he was the survivor. In the first calamity, among other keenly-felt disappointments, he witnessed the dispersion of his noble library, of more than 10,000 volumes collected with superior judgment and attention. On this melancholy reverse he was surrounded by a few much respected and truly respectable friends, who administered every consolation to his wounded feelings that benevolence and philanthropy could suggest (for to a mind liko his, of exquisite sensibility, his sufferings were in the highest degree acute;) but after his first shock had subsided, his conscious rectitude and unimpeached integrity enabled him to sustain his situation with the dignified composure of a philosopher, and the resignation of a Christian. He was a member of the religious society of Friends, to which he adhered through life, and maintained its principles with unvarying consistency. His political sentiments were uniform, and were those of the Old Whigs; to several of the leading characters of which party he wus intimately known about the middle of the last century. Of so excellent, so estimable an individual, this is a brief, and very imperfect record; but while memory remains, his friends will not cease to revere a character equally distinguished by powers of intellect, moral rectitude, liberality of sentiment, and urbsnity of manners," 
Miss Collinson thus continues the history of the fumily,-in ber letter to Dr. Darlington,- “ Michael Collinson died in 1795, leaving a son (my father), Charles Streynsham, and a daughter Marian, (Mrs. Close,) who died in 1826. Mary (Mrs. Cator) died in 1804, without children.

My father returned to England in 1798, after thirty years residence in India. My aunt, Mrs. Close, left one son, Edward, now (I believe) a judge in New South Wales,-married, and has children; but soon after his mother's death he dropped all correspondence with my father. My father had eleven children; one boy died in childhood; but ten survived their father, and lived to grow up ; and now we are but five. My three beloved, amiable, and brave brothers, were all taken from us within two years! The second (William Clinton Peter,) in the 37 th Regiment, N. T., died on the 30th January, 1840, of a severe wound received at the taking of Pushoot; the third (Henry Redfearn,) of yellow fever, 8th May, 1840, in Jamaica, whilst with his Regiment, the 64 th ; and the eldest, a captain in the 18th Royal Irish, was killed, July 21st, 1842, at the taking of ChinKang-Fou, in China: all three deserving of the numerous and high testimonies to their worth, which we have received in letters from the officers of their several regiments. One sister died in Leamington of a decline, in 1843; and another, last year, fell a victim to that fearful scourge, cholera, at Boulogne, in France. It has pleased our Almighty Father most repeatedly and severely to afflict us; and though his mercy has enabled us to bear these heavy trials, yet no time has yet enabled me to dwell or write upon them with compo. sure.

Two of my sisters are married, and have children. I believe, now, all the descendants of our worthy ancestor, bearing the name of Collinson, are my two sisters, Emily Frances, and Louisa,-and myself. It is a sad retrospect $I$ have gone through, and you must, dear sir, pardon any expression of my feelings, I have been led to intrude upon you, in writing upon this melancholy subject."

In a recent communication to the writer, Dr. Darlington says, "From subsequent letters of my esteemed correspondent, Miss Anna Maria Collinson, we learn that her two married sisters are named Octavia Aylmer, and Georgiana Custance. Which is the elder we know not; but we gather from the letters, that Mrs. Aylmer resides at Bath, - and Mrs. Custance at Brussels. They have also an uncle (Colonel Sowerby) in Hertfordshire, Wales. It seems truly remarkable, and melancholy, that nearly all the male posterity of the good 


\section{C58 D5}

old Quaker should have become soldiers, and died in the military service of their country !" Miss Collinson says :

"We were always brought up to venerate the name of Peter Collin. son. My dear father (who truly was worthy of the name, - and inherited the virtues, if not the extent of knowledge, of the great Peter,) was excessively fond of, and understood his garden."

In closing this appendix we borrow from Dr. Wood's late centennial discourse upon the Pennsylvania Hospital, his reference to Dr. Fothergill, the most intimate friend of Peter Collinson; and whose relations to the Hospital were analogous to those of Peter to the Library.

"It would be unpardonable to pass without notice the name of Dr. John Fothergill, of London, who was untiring in his good offices, not only subscribing largely of money, and making valuable donations of books, anatomical models, drawings, \&c., and exerting his influence in England in various ways for the good of the Hospital."

In a note to this interesting discourse he gives us a particular description of the character and important influence of these donations.

Dr. Wood brings prominently to view how much one of our first and best public Institutions owes to the efforts of Friends, and particularly to a London Friend, who was also Peter Collinson's friend. 


\section{Gaylord SPEEDY BINDER \\ Syracuse, N. Y. Stockton, Colif.}

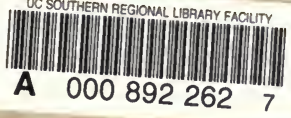

Qk

THE LIBRARY 
